\title{
Prostatic Glandular Cell
}

National Cancer Institute

\section{Source}

National Cancer Institute. Prostatic Glandular Cell. NCI Thesaurus. Code C33409.

A secretory cell that produces and secretes prostatic fluid. Prostatic fluid contains citric acid, the enzyme fibrinolysin that liquefies the semen, acid phosphatase, a number of other enzymes and lipids. The secretion of the prostate is the first fraction of the ejaculate. 